\title{
ПЕРСОНАЛІСТИЧНА МОДЕЛЬ БІОЕТИКИ ЯК ЕТИЧНА ЗАСАДА МЕДСЕСТРИНСТВА
}

\author{
O. I. Боєва
}

КЗ «Павлоградська міська лікарня № 1 дОР»

\begin{abstract}
Сучасні вимоги до якості медичних послуг, реформування і удосконалення вітчизняної медичної служби спонукали нас вивчити роль біоетичної обізнаності медичного персоналу лікарні у забезпеченні належної якості медичної допомоги. Один раз на місяць проводимо анонімне анкетування стаціонарних пацієнтів щодо дотримання етики та деонтології медпрацівниками у стаціонарних відділеннях, щодо якості надання медичної допомоги хворим стаціонарних відділень, щодо якості харчування хворих стаціонарних відділень. Результати анкетування показують, що успішна медсестринська практика має грунтуватися на етичних засадах персоналістичної моделі біоетики.
\end{abstract}

\section{PERSONALISTIC MODEL OF BIOETHICS AS ETHICAL PRINCIPLES OF NURSING}

\section{O. I. Boyeva}

\section{Pavlohrad City Hospital № 1}

Current requirements for quality health services reform and improvement of the national health service prompted us to examine the role of bioethical awareness among hospital staff to ensure proper quality of care. Once a month, an anonymous survey was conducted for stationary patients to comply with ethics and deontology of medical staff in hospital, on the quality of medical care inpatient departments and about the quality of food patients inpatient departments. The survey results show that successful nursing practice should be based on ethical principles of personalistic bioethics model.

Вступ. Біоетика або етика життя - це розділ прикладної етики, філософської дисципліни, що вивчає проблеми моралі насамперед стосовно людини, визначає, які дії з морального погляду є припустимими, а які - неприпустимими. Або іншими словами: біоетика це органічне поєднання новітніх досягнень біологічної науки та медицини з духовністю. У сучасному суспільстві вона стала ознакою цивілізованості.

Сучасний стрімкий розвиток біологічної науки відкрив принципово нові методи лікування хворих, відтворення організмів, нові можливості в розвитку біотехнологій. Коло проблем, що вимагають розгляду з позицій біоетики, включає зокрема біоетику допоміжних репродуктивних технологій і профілактики вроджених вад розвитку; біоетичні аспекти клінічних випробувань, реєстрації нових лікарських засобів і медичних технологій; етичні аспекти клінічної практики; експерименти на тваринах і альтернативні методи досліджень у біології й медицині; екологічну етику і безпеку сільськогосподарської продукції. Сучасні ви-

(c) О. І. Боєва, 2017 моги до якості медичних послуг, реформування і удосконалення вітчизняної медичної служби спонукали нас вивчити роль біоетичної обізнаності медичного персоналу лікарні у забезпеченні належної якості медичної допомоги.

Основна частина. Принципи біоетики тісно пов'язані з питаннями регулювання медичної діяльності та вносять чіткість у розуміння зв'язку біомедичної етики і права. Можна виділити такі принципи персоналістичної моделі біоетики: принцип пошани людської гідності, принцип «твори добро і не заподіюй зла», принцип визнання автономії особи і принцип справедливості. Правила поводження медичного персоналу це правдивість, конфіденційність, недоторканність приватного життя і добровільна інформована згода. В сукупності вони утворюють етичні «координати», що описують ставлення до пацієнта як до особи [1].

Один раз на місяць у КЗ «Павлоградська міська лікарня № 1 дОР» проводимо анонімне анкетування стаціонарних пацієнтів щодо дотримання етики та деонтології медпрацівниками у стаціонарних відділен- 
нях, щодо якості надання медичної допомоги хворим стаціонарних відділень, щодо якості харчування хворих стаціонарних відділень. Результати анкетування показують, що успішна медсестринська практика має ґрунтуватися на етичних засадах персоналістичної моделі біоетики. Ці основні етичні принципи включають наступне.

Під автономією особи пацієнта розуміють фізичну і психічну недоторканність при наданні медичної допомоги. Ключова ознака автономії пацієнта - право пацієнта приймати рішення щодо медичних втручань, які здійснюються лише за його згоди. Етична цінність автономії пацієнта полягає в тому, що дії лікаря спрямовані на благо хворого з метою його одужання, на основі поваги до гідності та прав пацієнта.

Процес інформування пацієнта, завдяки якому останній набуває знань, повинен проводитися так, щоб у неосвіченої спочатку людини з'явилася певна компетентність щодо стану свого здоров'я і тих маніпуляцій, які щодо нього планують здійснити медпрацівники. Робота медсестри у медичному закладі вимагає суворої дисципліни, медсестра повинна дотримуватися субординації і точно виконувати розпорядження лікаря, тобто має бути службове підпорядкування молодшого за посадою до старшого. Медсестра у ставленні до хворих повина бути ввічливою, уважною, доброзичливою. Водночас медсестрі необхідно дотримуватись єдиної тактики із лікарем щодо інформування пацієнта про його хворобу та процес лікування. Пацієнт має право отримати правдиву інформацію про стан свого здоров'я, результати діагностичних обстежень, але цю інформацію потрібно подавати обережно, делікатно, уникаючи стресової реакції з боку пацієнта. Медичний персонал повинен пам'ятати про недопустимість ятрогенії. Важливим питанням $\epsilon$ також нерозголошення приватних даних пацієнта. Це положення знаходиться у повній відповідності з принципом автономії особи пацієнта. Відповідно до Декларації про політику в галузі забезпечення прав пацієнта в Європі (1994) інформація повинна надаватися пацієнту з урахуванням рівня його освіченості $з$ мінімальним вживанням незнайомої для нього спеціальної термінології. Якщо пацієнт відмовляється від цієї інформації, відмова від інформації повинна бути закріплена письмово.

Принцип справедливості в галузі біомедичної етики полягає у тому, що кожен пацієнт, незалежно від соціального походження, матеріального стану, інших чинників, має право на отримання рівного обсягу медичної допомоги і рівного доступу до медичних ресурсів.

Таким чином, значення принципів біомедичної етики полягає у визначенні загальних напрямів ії розвитку, появі нових положень, що регулюють ті чи інші суспільні відносини в медицині. За даними сучасних досліджень, дотримання прав пацієнтів в Україні, право на індивідуальний підхід і право на інформацію погано забезпечені. На відміну від інших прав пацієнтів, забезпечення яких вимагає економічних і державних реформ, ці два права (право на індивідуальний підхід і право на інформацію) можна забезпечити через покращання фахової освіти медичних працівників і формування у них комунікативних навичок та емпатичного співчутливого ставлення до хворих [2]. Актуальною проблемою сьогодення $\epsilon$ формування правил поведінки медичних працівників, мистецтва індивідуального підходу до особистості хворого, його психічного та емоційного станів, пов'язаних із захворюванням [3].

Завжди слід пам'ятати про існування лікарської (медичної) таємниці (право пацієнта на конфіденційність). До неї належить «інформація про факт звернення за медичною допомогою, стан здоров'я громадянина, діагноз його захворювання й інші відомості, отримані при його обстеженні та лікуванні».

Обов'язок збереження інформації про пацієнта покладений і на сучасних лікарів, так відповідно до Клятви лікаря, що затверджена Указом Президента України від 15 червня 1992 р. № 349, кожен лікар зобов'язується зберігати лікарську таємницю, не використовувати ії на шкоду людині. Цивільний кодекс України від 16 січня 2003 р. № 435-IV (зі змінами і доповненнями) надає право фізичній особі на таємницю про стан свого здоров'я, факт звернення за медичною допомогою, діагноз, а також про відомості, отримані при їі медичному обстеженні (ч. 1 ст. 286). Практично ідентичною за змістом є стаття 39-1 «Основ законодавства України про охорону здоров'я» від 19 листопада 1992 р. № 2801-XII (зі змінами і доповненнями). Відповідно до цієї статті пацієнт має право на таємницю про стан свого здоров'я, факт звернення за медичною допомогою, діагноз, а також про відомості, отримані при його медичному обстеженні [4].

Медсестра, обслуговуючи всіх членів сім'і, мимоволі буває поінформована про внутрішньосімейні проблеми і повинна бути готовою дати кваліфіковану пораду щодо вирішення конфліктних ситуацій, соціальних проблем. Останніми роками отримала 
широке визнання думка про введення в програми навчання медсестер усіх рівнів соціально-психологічної підготовки, оскільки соціально-психологічна компетентність медсестри лежить в основі встановлення терапевтичного альянсу з пацієнтом, корелює з психологічним ефектом лікування [5].

\section{СПИСОК ЛІТЕРАТУРИ}

1. Біоетика : підручник / Е. Згречча, А. Дж. Спаньйоло, М. Л. П'єтро та ін. ; пер. з італійської В. Й. Шовкун. - Львів: лОБФ «Медицина і право», 2007. - 672 с.

2. Маргаева М. П. Значимость формирования и развития коммуникативных навыков у студентов медицинских училищ и колледжей / М. П. Маргаева, Н. Н. Лебедева // Медсестра. - 2014. - № 3. - С. 35-38.

3. Пустовит С. В. Современная европейская биоэтика / С. В. Пустовит // П'ятий національний конгрес з біоетики
Висновок. Принципи персоналістичної моделі медичної біоетики властиві традиціям вітчизняної медичної служби, підтримані існуючими статтями законодавства медичного спрямування і можуть слугувати етичними засадами надання медсестринського догляду.

з міжнародною участю, 23-25 вересня 2013 р. : тези доп. К., 2013. - C. 39-42.

4. Закон України «Основи законодавства України про охорону здоров'я [Електронний ресурс] // Відомості Верховної Ради України (ВВР). - 1993. - № 4. - С. 19. - Режим доступу : http://zakon0.rada.gov.ua/laws/show/2801-12

5. Лавриш Ю. Е. Професійна підготовка медичних сестер в університетах Канади : автореф. дис. на здобуття наук. ступеня канд. пед. наук : спец. 13.00.04 «Теорія і методика професійної освіти» / Ю. Е. Лавриш. - К., 2009. - 23 с. 